\title{
EFEKTIVITAS CACING TANAH (Lumbricus rubellus) SEBAGAI PENGENDALIAN Salmonella sp. PADA AYAM BROILER
}

\author{
Effectiveness of Earthworm (Lumbricus rubellus) to Control of Salmonella sp. On \\ Chicken Broiler
}

\author{
Suprayoga', Ma'ruf Tafsin ${ }^{2}$ dan Tri Hesti Wahyuni ${ }^{2}$ \\ 1. Mahasiswa Program Studi Peternakan Fakultas Pertanian Universitas SumateraUtara \\ 2. Staf Pengajar Program Studi Peternakan Fakultas Pertanian Universitas Sumatera Utara
}

\begin{abstract}
Salmonellosis disease controled using antibiotics can be a residued that continuous used of antibiotics can lead to inefficient and microbe resistant. This study aims to determine the effectivity of eatrhworm product to control Salmonella sp. The product of earthworms were gived in the form of extracts, flour and porridge. The research composed of there stage, first stages were adition earthworms in agar medium, the secound stage were determined the sensitivity against Salmonella sp and third stage were challenge test used 20 broiler chickens. This study used a completely randomized design (CRD) with five treatment and four replication. The treatment composed of control (P0), commercial antibiotics (P1), extract (P2), flour (P3) and pulp (P4). Challenge test used Salmonella sp $\left(10^{6} \mathrm{CFU} / \mathrm{gird}\right)$ at the age 12 days. The results of the first stage showed that the growth of Salmonella sp colonies can be decreased by earthworms product. At the second stage showed that Salmonella sp had high sensitivity on earthworms. The result at third stage showed there earthworm product had ability to control Salmonella sp in broiler chicken. It is concluded that Salmonella sp can be controlled by earthworm product, and the extract showed the best product.
\end{abstract}

Keywords: Earthworm, Salmonella Sp, Broiler Chickens, Control

\begin{abstract}
ABSTRAK
Pengendalian penyakit salmonellosis mengunakan antibiotik dapat meninggalkan residu sehingga pengunaan antibiotik yang terus menerus dan tidak efisien dapat menyebabkan mikroba resisten. Penelitian ini bertujuan untuk mengetahui tingkat pengendalian Salmonella sp dengan olahan cacing tanah dalam bentuk ekstrak, tepung dan bubur cacing tanah. Tahapan yang digunakan dalam penelitian adalah: Tahap I mengimbuhkan cacing tanah kedalam media agar, Tahap II uji sensitifitas Salmonella sp. Tahap III uji tantang pada 20 ekor ayam broiler, penelitian ini mengunakan rancangan acak lengkap (RAL) dengan lima perlakuan yaitu kontrol (P0), antibiotik komersil (P1), ekstrak (P2), tepung (P3) dan bubur (P4). Hasil penelitian pada tahap I menunjukan bahwa pertumbuhan koloni Salmonella sp dapat diturunkan dengan olahan cacing tanah. Tahap II memiliki hasil penelitian Salmonella $s p$ mempunyai tingkat sensitifitas yang tinggi terhadap olahan cacing tanah. Tahap III uji tantang pada ayam broiler bahwa olahan cacing tanah dapat mengendalikan pertumbuhan Salmonella sp secara signifikan, dari hasil penelitian dapat disimpulan bahwa Salmonella sp dapat dikendalikan dengan olahan cacing tanah dan ekstrak cacing tanah merupakan olahan terbaik.Kata kunci: Cacing Tanah, Salmonella Sp, Ayam Broiler, Pengendalian
\end{abstract}

Kata kunci: Cacing Tanah, Salmonella Sp, Ayam Broiler, Pengendalian 


\section{PENDAHULUAN}

Salmonellosis merupakan penyakit menular yang bersifat zoonosis dan termasuk food borne disease yaitu suatu penyakit yang diderita oleh seseorang akibat mengkonsumsi makanan yang telah terkontaminasi oleh mikroba patogen. Kejadian salmonellosis pada manusia yang sering dilaporkan akibat tertular produk-produk asal ternak unggas seperti telur dan daging terkontaminasi.

Penyakit salmonellosis merupakan penyakit unggas yang disebabkan oleh infeksi bakteri Salmonella sp. Penyakit salmonellosis dapat menyebabkan kematian jika menyerang unggas muda pada umur $\leq 3$ minggu dengan tingkat mortalitas antara 20-80\% (Porter, 1998; Purnomo, 2004). Salmonella sp adalah bakteri gram negatif yang dapat menekan sistem kekebalan tubuh unggas (immuno-suppression) dan menyebabkan kematian ayam pedaging (Shivaprasad, 2003; Mcmullin, 2004).

Habitat bakteri Salmonella sp di dalam alat pencernaan manusia, hewan, dan bangsa burung. Oleh karena itu cara penularannya adalah melalui mulut karena makan/minum bahan yang tercemar oleh keluaran alat pencernaan penderita. Salmonella sp akan berkambangbiak di dalam alat pencernaan penderita, sehingga terjadi radang usus (enteritis). Radang usus serta penghancuran Lamina propria alat pencernaan oleh penyusupan (proliferasi) Salmonella $s p$ dapat menimbulkan diare, karena Salmonella $s p$ menghasilkan racun yang disebut Cytotoxin dan Enterotoxin (Dharmojono, 2001).

Antibiotik diberikan sebagai bahan imbuhan penyusun ransum yang bertujuan antibiotic growth promotor (AGP) efek penggunaan antibiotik yang terus menerus dan pengunaanya yang tidak tepat akan menyebabkan mikroba resisten. Berbagai upaya dilakukan untuk mencari pengganti antibiotik sebagai AGP, karena semakin meningkatnya kecenderungan akan permintaan produk peternakan yang sehat, aman, dan bebas dari residu berbahaya. pemanfaatan bahan alam yang relatif aman untuk mencegah penyakit. L.rubellus yang mengandung protein tinggi dan asam amino lengkap menjadi salah satu alternatif yang potensial untuk dijadikan bahan pakan.

L.rubellus memiliki kadar protein kasar $65,63 \%$ dan asam amino prolin sekitar $15 \%$ dari total 62 asam amino. (L. rubellus) terbukti mempunyai daya antimikroba dengan spektrum luas. Peptida Lumbricin I sebagai senyawa yang bertanggung jawab atas aktivitas antimikroba spektrum luas pada L.rubellus (L. rubellus) (Cho, 1998).

L.rubellus memiliki berapa cara pengolahan seperti pembuatan tepung, bubur dan ekstraksi, pengolahan L.rubellus tersebut memiliki kekurangan dan kelebihan sehingga 
menimbulkan minat penulis untuk membandingkan dan meneliti dari efektifitas pengendalian Salmonella dengan berbagai pengolahan L.rubellus.

\section{BAHAN DAN METODE PENELITIAN}

\section{Waktu dan Tempat Penelitian}

Penelitian ini dilaksanakan di Laboraturium Reproduksi Programstudi Peternakan Universitas Sumatera Utara, J1. A. Sofyan No. 3 Kampus Universitas Sumatera Utara, Medan. Penelitian ini dilaksanakan selama 3 bulan

\section{Tahap I. Isolasi Salmonella Sp}

\section{Bahan}

Bahan yang digunakan dalam penelitin pada tahap I adalah L.rubellus segar yang diolah sesuai dengan perlakuan, Brain Heart Infusion (BHI) Agar dan SSA (Salmonella sighella agar) sebagai media biakan Salmonella sp, alkohol, aquades, alumunium foil, kapas, tisu, sarung tangan, isolat Salmonella sp didapatkan dari hasil isolasi Salmonella sp dari kotoran ayam dan plastik cling warp.

Alat

Alat tahap I yang digunakan dalam penelitian ini adalah cawan petri, pipet mikro, kawat ose, aoutoclaf, pipet tetes, tabung reaksi, bunsen, gelas erlemeyer, gelas ukur dan masker.

\section{Metode}

Metode yang digunakan pada tahap I adalah menghitung CFU (colony farming unit) yang dikemukakan dalam penelitian Gast (1997). Prosedur yang digunakan dalam metode ini yaitu: pertama dibuat isolat Salmonella sp dengan pemurnian Salmonella dengan media SSA dan media TSI kemudian uji pewarnaan dengan methylen red. Diisolatkan kotoran ayam pada media padat SSA kemudian diinkubasi pada suhu $30^{\circ} \mathrm{C}$ selama 24 jam. Dipindahkan Salmonella ke media SSA yang baru kemudian diuji Salmonella yang sudah di dapat dengan media TSI dan dilanjutkan dengan pewarnaan dengan methylan red. Isolat Salmonella sp di imbuhkan sebesar satu ml ke media SSA yang telah diberi imbuhan perlakuan dan dihitung kolonial Salmonellanya dalam bentuk CFU. 


\title{
Tahap II. Uji Sensitivitas Salmonella L.rubellus
}

\section{Bahan}

Bahan bahan yang digunakan dalam penelitin pada tahap II adalah L.rubellus segar yang diolah sesuai dengan perlakuan, Salmonella sighell agar (SSA) sebagai media biakan Salmonella sp, alkohol, aquades, alumunium foil, kapas, tisu, sarung tangan. Isolat Salmonella sp didapatkan dari hasil isolasi Salmonella sp tahap I dan plastik cling warp.

\begin{abstract}
Alat
Alat yang digunakan dalam tahap II adalah cawan petri, pipet mikro, kawat ose, aoutoclaf, pipet tetes, tabung reaksi, bunsen, gelas erlemeyer, gelas ukur, vortex atau mixer bertujuan untuk melarutkan zat-zat yang terkandung dalam L. rubellus, centrifuge digunakan untuk memisahkan cairan dari supernatanya dan masker.
\end{abstract}

\section{Metode}

Metode yang digunakan pada tahap II adalah metode kertas cakram yang bertujuan untuk menyimpan larutan perlakuan yang ditambah ke media. Pelaksanaan tahap II dimulai dengan menyiapkan media agar padat kemudian diisolasikan isolat Salmonella sp dari media cair yang telah diencerkan hingga CFU-nya $10^{8}-10^{9}$ kemudian dilakukan inkubasi media pada suhu $\pm 30^{0} \mathrm{C}$ di inkubator selama 24-36 jam. Ditambahkan kertas cakram yang telah diisi perlakuandan L.rubellus, diinkubasikan kembali diukur diameter daerah bening pada media.

\section{Tahap III. Uji Tantang Menggunakan Ayam Broiler}

\section{Bahan}

Bahan-bahan yang digunakan pada tahap III adalah L.rubellus segar yang sudah diolah dan siap dijadikan perlakuan, ayam broiler sebagai media uji tantang, aquades, sarung tangan, isolat Salmonella sp, alkohol dan pakan ayam.

\begin{abstract}
Alat
Alat yang digunakan pada tahap III adalah kandang individual dengan ukuran $25 \times 32 \mathrm{~cm}$, tempat pakan, tempat minum, spuit $30 \mathrm{ml}$ sebagai alat pencekok, tempat penampungan feses, media padat SSA, cawan petri, autoclaf, centrfuge, vortex atau mixer, pipet tetes, inkubator, tabung reaksi, kawat ose, dan sarung tangan.
\end{abstract}

\section{Metode}


Tahap III menggunakan metode uji tantang pada penelitiaan yaitu dengan menginangkan Salmonella sp pada ternak ayam dan diberi perlakuan sehingga dapat diketahui pertumbuhan dan perkembangan Salmonella sp apakah perlakuan dapat mengendalikan pertumbuhan Salmonella sp pada inangya. Prosedur yang digunakan dalam metode ini yakni penampungan feses ayam selama 4 hari pertama sebelum perlakuan pada kandang metabolis dan dihitung CFU-nya, kemudian dicekokan isolat Salmonella sp dengan konsentrasi $\pm 10^{6}$ pada hari ke 5 dan penampungan feses dilakukan hari ke 6 sampai hari ke 9 (masa inkubasi) dan dihitung CFU-nya pada feses. Setelah masa inkubasi hari ke 10 sampai ke 13 dilakukan penampungan feses ayam yang telah terinfeksi dan dihitung CFU-nya pada feses.

\section{Metode Penelitian}

Rancangan yang digunakan adalah rancangan acak lengkap (RAL) yang terdiri atas 5 perlakuan dan 4 ulangan,

Perlakuan yang diteliti antara lain;

$\mathrm{P} 0=$ infeksi Salmonella $($ kontrol)

$\mathrm{P} 1=$ infeksi Salmonella + pengendalian antibiotik

P2 = infeksi Salmonella + pengendalia ekstrak L.rubellus

P3 = infeksi Salmonella + pengendalian tepung L.rubellus

$\mathrm{P} 4=$ infeksi Salmonella + pengendalian bubur L.rubellus

Metode linier RAL (rancangan acak lengkap) yang diasumsikan adalah:

\section{$Y i j=\mu+\sigma i+€ i j$}

Keterangan:

Yij = Respon atau nilai pengamatan dari perlakuan ke-i dan ulangan ke-j

$\mathrm{i} \quad=1,2,3 \ldots=$ perlakuan

$\mathrm{j} \quad=1,2,3 \ldots .=$ ulangan

$\mu \quad=$ nilai tengah umum

$\sigma \mathrm{i}=$ pengaruh perlakuan ke-i

$€ \mathrm{ij}=$ Pengaruh galat (Experimental Eror) 


\section{HASIL DAN PEMBAHASAN}

\section{Tahap I Isolasi Salmonella}

Prinsip dari penghitungan metode hitungan cawan adalah bila sel mikroba yang masih hidup ditumbuhkan pada medium, maka mikroba tersebut berkembang biak dan membentuk koloni yang dapat dilihat langsung dan kemudian dapat dihitung tanpa menggunakan mikroskop. Hasil pengamatan dari tahap I yaitu penghitungan total koloni Salmonella sp pada media SSA yang diimbuhkan perlakuan kedalamnya dapat dilihat pada Gambar 1.

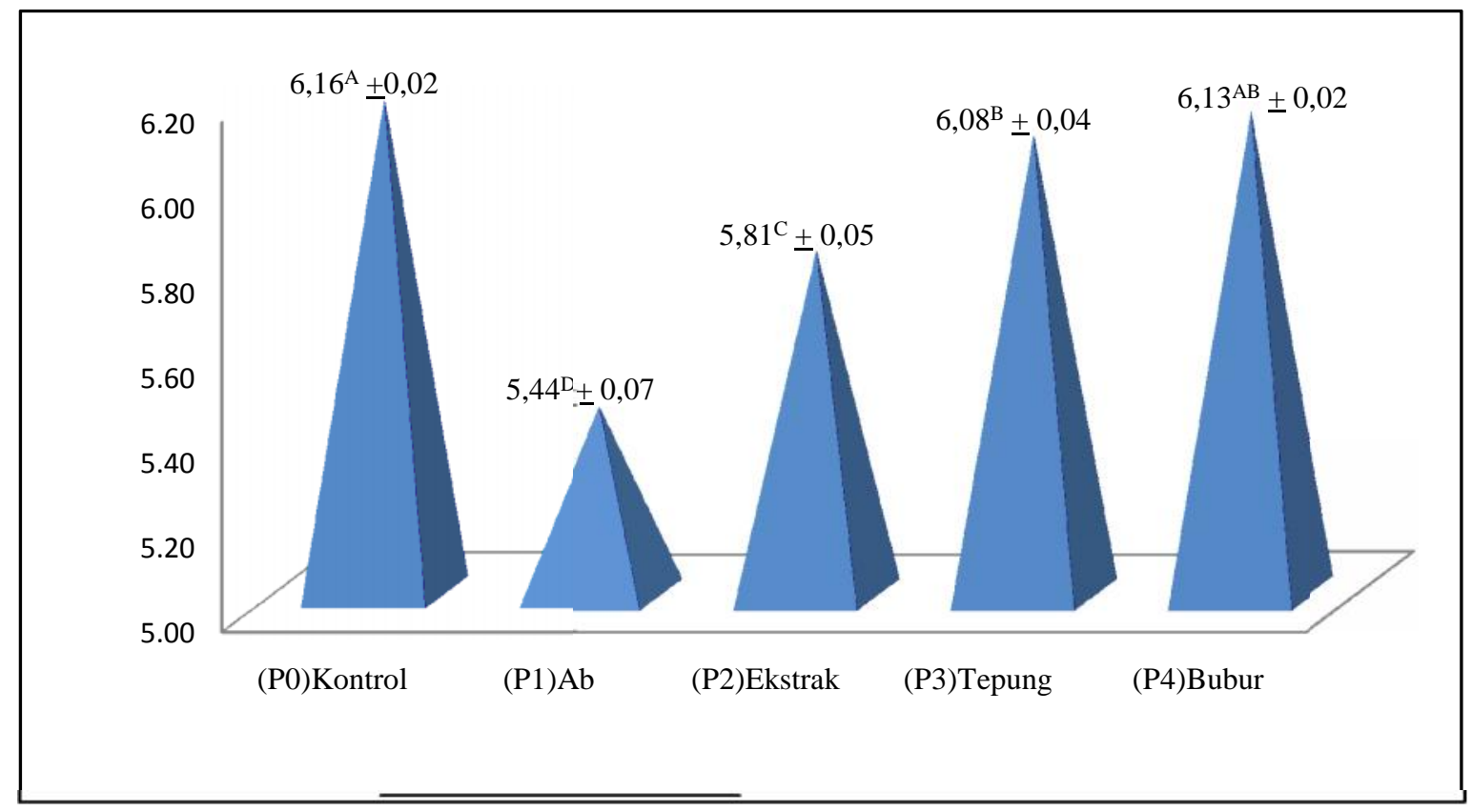

Gambar 1. Tahap I Isolasi Samonella sp pada Media Berimbuhan L.rubellus.

Berdasarkan Gambar 1 dapat dilihat rataan tertinggi pada perlakuan (P0) kontrol yaitu sebesar 6,16 Log CFU. Pada P0 media tidak mendapatkan imbuhan antibiotik buatan maupun komersil dan diikuti dengan (P4) bubur L.rubellus sebesar 6,13 Log CFU, bubur L.rubellus sebesar 0,1 ml diimbuhkan ke media SSA, kemudian disusul dengan P3 sebesar 6,08 Log CFU pada pada P3 mendapatkan imbuhan tepung L.rubellus sebesar 0,1g dalam media, dan diikuti dengan P2 sebesar 5, 81 Log CFU perlakuan P2 mendapatkan imbuhan ekstrak L.rubellus sebesar $0,1 \mathrm{ml}$ hingga perlakuan terendah pada perlakuan (P1) Ab atau penggunaan antibiotik komersil sebesar 5,44 Log CFU pada setiap perlakuan mengikiti dosis penggunaan antibiotik komersil sebesar $0,1 \mathrm{ml}$. 
Setiap perlakuan memiliki total koloni yang sangat berbeda kecuali pada perlakuan P4 sebesar 6,13 yang mendekati perlakuan P0 sebesar 6,16 dan perlakuan P3 sebesar 6,07. Perbedaan ini dapat disebabkan oleh banyaknya asam amino yang terkandung dalam L.rubellus, dan mengandung berbagai jenis enzim. penelitian menjelaskan bahwa L.rubellus mengandung enzim Lumbrokinase, peroksidase, katalase, dan selulose (Palungkun, 2008). Lumbrokinase merupakan salah satu enzim yang bertanggung jawab dalam mengendalikan patogen pada saluran pencernaan, enzim- enzim pada L. rubellus besifat alkaloid dan hanya bereaksi pada pelarut basa sehingga bisa diserap tubuh (Mihara et al., 1991), Pada perlakuan P4 atau bubur L. rubellus tidak mendapatkan pelarut basa karena hanya melalui proses pasteurisasi saja.

Hasil analisis sidik ragam menunjukan bahwa perbedaan imbuhan pada media tanam Salmonella sp dengan L.rubellus memberikan perbedaan yang nyata terhadap jumlah koloni Salmonella.

Mihara et al., (1991) menjelaskan bahwa kandungan lumbritin dan enzim-enzim yang berada pada L. rubellus tidak mudah larut karena bersifat alkaloid sehingga pada perlakuan (P4) bubur L.rubellus tidak mendapatkan reaksi yang berbeda jauh dengan perlakuan (P3) dikarenakan antimikroba yang tidak bereaksi secara sempurna, hal ini dapat dilihat dari P4 tidak berbeda nyata dengan P0 yang tidak memiliki antimikroba.

\section{Tahap II Uji Luas Zona Bening}

Resistensi merupakan zona hambat antibiotik yang terjadi terhadap bakteri, sedangkan sensitifitas merupakan zona hambat yang tidak terjadi pada antibiotik terhadap bakteri, maka zona bening adalah sensitifitas bakteri terhadap anti bakteri. Hal ini sejalan dengan pendapat Cappuccino (1978) yang mengatakan bahwa diameter zona hambatan disebabkan antibiotik atau patogenesis.

Analisis ragam pada zona bening menunjukkan $\mathrm{F}$ hitung lebih besar dari $\mathrm{F}$ tabel 0,05 sehingga dilakukan uji lanjut menggunakan uji duncan. Pada uji lanjut didapati bahwa setiap perlakuan memiliki perbedaan yang dapat dilihat dari rataan tertinggi pada P1 sebesar 23,30 mm dan diikuti secara berturut-turut P2 sebesar 18,40 mm, P3 sebesar 15,50 mm, P4 sebesar 12,75 mm dan terendah pada P0. Perbedaan ini juga dapat dilihat dari notasi dari setiap perlakuan yang berbeda antar satu perlakuan dengan perlakuan yang lain. 


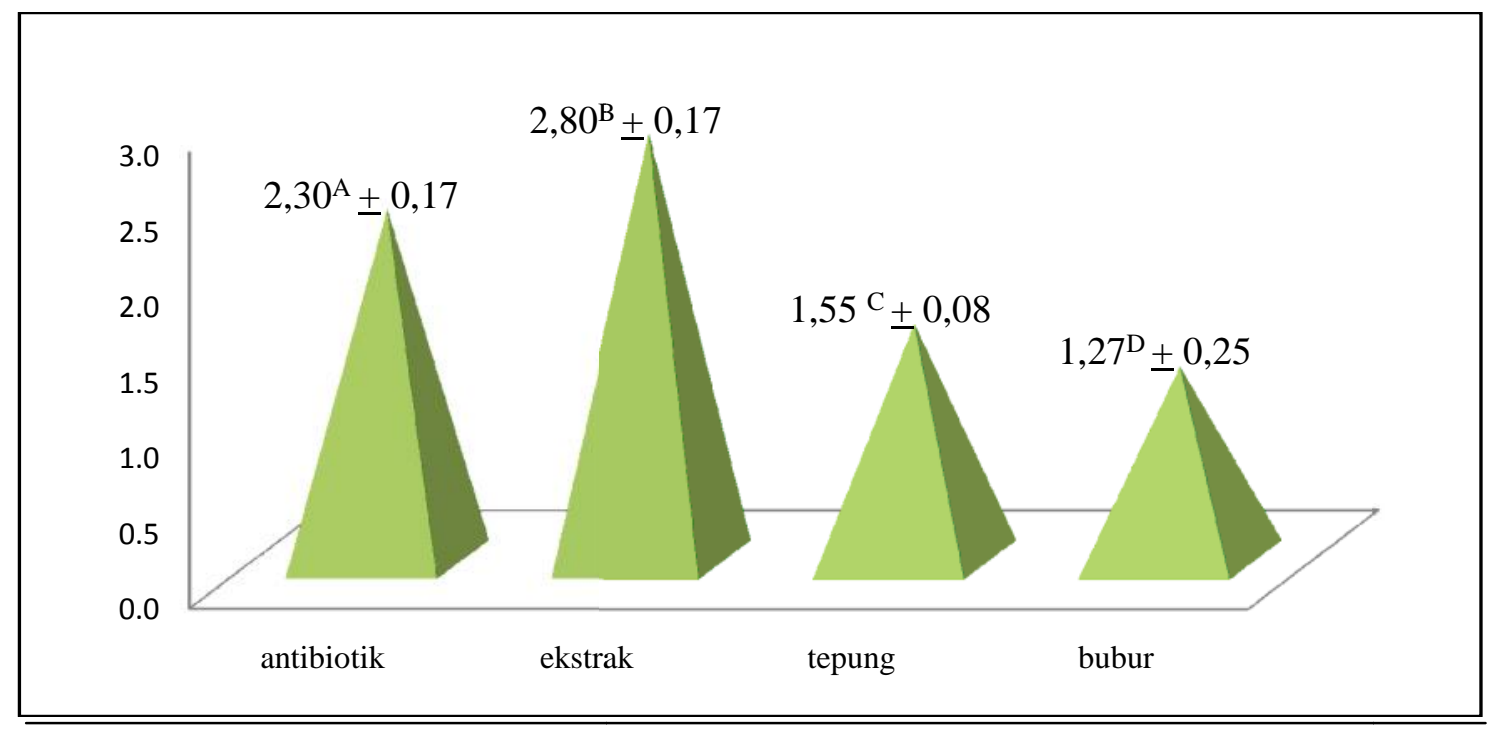

Gambar 2. Luas Zona Bening (mm) Sensitivitas Salmonella sp terhadap L.rubellus.

Kontrol negatif (P0) merupakan perlakuan yang tidak diberi apapun kedalamnya dan bertujuan untuk mengetahui jumlah dan tingkat pertumbuhan Salmonella sp secara normal. Pada P0 tidak memiliki luas zona bening karena tidak memiliki zat antimikroba. (P1) antibiotik komersil memiliki diameter zona hambatan sebesar 23,30 mm pada masa inkubasi 24 jam dan diikuti berturut-turut dengan perlakuan (P2) ekstrak L.rubellus memiliki diameter 18,40 mm, (P3) tepung L.rubellus sebesar 15,50 mm dan yang terkecil pada perlakuan (P4) bubur L.rubellus sebesar 12,75 mm. Menurut Baehaki et al., (2011) indeksa zona bening dinyatakan positif bila zona bening $\geq 1,00 \mathrm{~cm}$.

Berdasarkan hasil uji pengukuran diameter daerah hambatan dari sampel menunjukkan bahwa setiap jenis sampel uji dengan konsentrasi berbeda memilki kemampuan dalam menghambat pertumbuhan bakteri Salmonella $s p$ dengan diameter hambatan yang berbeda. Menurut Mary (1992) hal tersebut dapat disebabkan karena adanya perbedaan konsentrasi senyawa aktif yang bersifat sebagai antimikroba pada masing-masing konsentrasi dan jenis sampel uji. Konsentrasi bahan kimia mempengaruhi pertumbuhan mikroorganisme. Dalam konsentrasi kecil bersifat menghambat pertumbuhan mikroorganisme (Lay, 1994).

Menurut Lay (1994) perbedaan besarnya daerah hambatan untuk masing-masing konsentrasi dapat diakibatkan antara lain perbedaan besar kecilnya konsentrasi atau banyak sedikitnya kandungan zat aktif antimikroba yang terkandung di dalamnya serta kecepatan difusi bahan antimikroba ke dalam medium. Faktor-faktor lain yang juga dianggap dapat mempengaruhi antara lain kepekaan pertumbuhan bakteri, reaksi antara bahan aktif dengan medium dan temperatur inkubasi. Beberapa faktor yang juga mempengaruhi hal ini antara 
lain pH lingkungan, komponen media, stabilitas obat, ukuran inokulum, waktu inkubasi dan aktivitas metabolik mikroorganisme (Brooks, et al., 2005).

\section{Tahap III Uji Tantang Salmonella sp Dengan L.rubellus Pada Ayam Broiler}

Isolat Salmonella sp didapatkan pada sampel manur ayam menggunakan metode swab. Isolat murni Salmonella sp dari media selektif selanjutnya dikonfirmasi dengan uji biokimia. Hasil uji biokimia dengan media TSI didapatkan reaksi berwarna kuning kemerahan. Hal ini menunjukkan isolat yang didapat tersebut hanya memfermentasi glukosa dalam media TSI. Reaksi positif dalam uji methyl red menunjukkan bahwa isolat tersebut mampu memetabolisme sumber karbon sitrat, memfermentasi campuran asam, butanediol dan glukosa, sesuai dengan karakteristik biokimia bakteri gram negatif Salmonella sp (Seeley et al., 2001).

Tabel 1. Uji Tantang Salmonella Dengan L.rubellus pada Ayam Broiler Log CFU

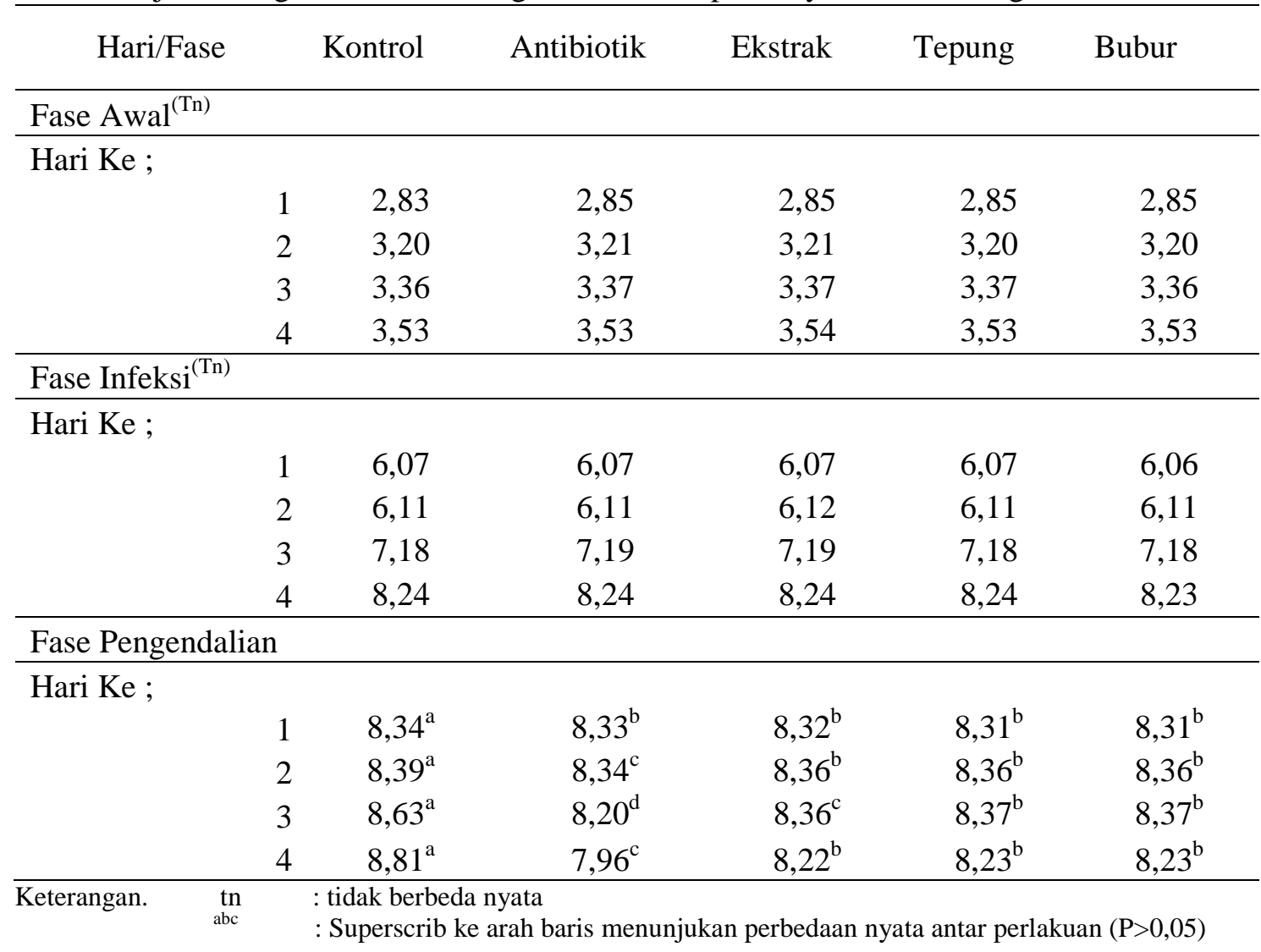

Uji sensitivitas pada tahap ini mejadi tiga fase, tahap pertama dimulai dari hari pertama hingga hari keempat bertujuan mengetahui tingkatan pertumbuhan Salmonella sp pada fase kosong (tidak mendapatkan perlakuan) hal ini sesuai dengan Gast (1997) dalam 
prosedur Uji serologis dan uji biologis antimikroba dilakukan dalam 3 tahapan, yaitu 1) 1 minggu sebelum infeksi bakteri, 2) 1 minggu masa infeksi dan 3) 1 minggu fase pengendalian.

Fase pertama terdiri atas empat hari pada umur ternak satu minggu. Pada fase pertama tidak memiliki perbedaan yang nyata antar perlakuan. Pada fase kedua mikroba yang di infeksikan (Salmonella sp) memiliki tingkat koloni $10^{6}$ CFU. Infeksi Salmonella sp dilakukan secara oral dan diamati pertumbuhan dan pertambahan koloninya melalui feses setiap harinya seperti yang tertera pada Tabel 1.

Tabel 1 menunjukkan bahwa setiap perlakuan perharinya tidak berbeda nyata hal ini disebabkan kondisi yang homogen dari setiap perlakuan. Pada hari ke 1 setiap perlakuan memiliki total koloni 6,06-6,07 Log CFU dan setiap harinya bertambah secara berturut-turut pada hari ke 2 sebesar 6,11-6,12 Log CFU, hari ke 3 sebesar 7,18-7,19 Log CFU hingga hari ke 4 pertumbuhan Salmonella sp semakin meningkat hingga 8,23-8,24 Log CFU.

Data di atas juga menjelaskan bahwa Salmonella sp yang diinjeksikan dapat beradaptasi, tumbuh dan berkembang dalam saluran pencernaan ayam broiler, hal ini dapat dilihat dari tingkat pertambahan koloni dari tiap harinya yang begitu pesat, dengan begini ayam broiler dianggap sakit dan sudah mengalami salmonelosis, sehingga dapat dilakukan tahap pengendalian atau fase tiga dari pemeliharaan.

Fase tiga Uji coba antibiotik ke ayam. Hari ke 1 setelah fase pengendalian perlakuan tertinggi pada P0 yaitu perlakuan kontrol negatif, ayam broiler ini tidak diberi perlakuan apaapa dan memiliki koloni sebesar 8,34 Log CFU yang berturut-turut diikuti oleh P1 perlakuan dengan antibiotik komersil sebesar 8,33 Log CFU, P2 dengan perlakuan ekstrak L.rubellus sebesar 8,32 Log CFU, P3 dengan perlakuan tepung L.rubellus memiliki koloni sebesar 8,31 Log CFU hingga perlakuan P4 bubur L.rubellus yang memiliki total koloni sebesar 8,31 Log CFU. Hal ini sesuai dengan Masduki (1996) kemampuan biologis setiap bakteri juga berbeda-beda dalam merespon bahan antibakteri. Salah satu faktor yang paling berpengaruh adalah adanya perbedaan struktur dinding sel antara bakteri gram negatif dan bakteri gram positif. Komponen khusus bakteri gram negatif terdiri atas lipoprotein, selaput luar, dan lipopolisakarida. Selaput luar dinding sel bakteri gram negatif merupakan selaput ganda fosfolipid yang sebagian besar diganti dengan molekul lipopolisakarida.

Analisis ragam di atas diketahui bahwa total Log CFU pada hari ke 1 pemeliharaan sangat berbeda nyata. Hal ini dapat dilihat dari $\mathrm{F}$ hitung lebih besar dari $\mathrm{F}$ tabel 0,05 pada $\mathrm{F}$ hitung dan harus dilakukan uji lanjut untuk lebih mengetahui tingkat keragamnya. 
Uji lanjut didapatkan bahwa setiap perlakuan memiliki nilai sensitive terhadap Salmonella dan hanya pada P0 (kontrol) pakan tanpa imbuhan antibiotik memiliki nilai yang tertinggi dengan nilai rataan 8,34 Log CFU sedangkan P1, P2, P3dan P4 tidak memiliki perbedaan yang nyata memiliki notasi B dari hasil uji lanjut. Hal ini bisa disebabkan total koloni didalam saluran pencernaan yang sangat tinggi dan anti biotik didak dapat secara spontanitas membunuh seluruh Salmonella $s p$ yang ada pada saluran pencernaan tetapi hanya mampu melisikannya seperti dikatakan Syamsiah, et al., (2005) bahwa antibakteri dalam ramuan herbal akan melisiskan racun yang menempel pada usus sehingga penyerapan zat makanan lebih meningkat.

Menurut Tafsin (2007) bakteri seperti Salmonella sp memiliki lektin pada permukaan selnya yang dapat mengenal gula spesifik dan membiarkan selnya untuk menempel pada gula tersebut, sehingga gula tersebut termediasi oleh bakteri tersebut, dengan penambahan L.rubellus dalam pakan maka lumbritin akan melindungi dinding saluran pencernaan dan Salmonella tidak dapat menempel dan menurunkan tingkat populasi dalam saluran pencernaan ternak.

Hari ke 2 fase pengendalian total koloni pada feses ayam dapat dilihat pada Tabel 5. Hari kedua fase pengendalian memang tidak memiliki perbedaan yang cukup siknifikan tetapi bila diuji analisis ragam diketahui bahwa $\mathrm{f}$ hitung lebih besar dari pada $\mathrm{f}$ tabel 0,05 sebesar 4,89 hal ini menunjukkan bahwasanya perlakuan sangat berbeda nyata sehingga dilakukan uji lanjut duncan. Uji lanjut duncan menjelaskan bahwa rataan tertinggi pada (P0) kontrol yang memiliki rataan 8,49 pada perlakuan tidak mendapatkan imbuhan antibiotik apapun, hal ini di ikuti dengan (P1) antibiotik, (P2) ekstrak L.rubellus, (P3) tepung L.rubellus yang memiliki notasi sama yaitu $B$ antara tiga perlakuan ini hal ini membuktikan bahwa tidak ada perbedaan yang nyata antara tiga perlakuan ini, ketiga perlakuan ini dapat melisiskan Salmonella dalam saluran pencernaan karena berbedan nyata dengan perlakuan P0 tetapi tidak sampai mengimbangi perlakuan P1 sebesar 8,34 hal ini sesuai dengan Syamsiah et al., (2005) antibiotik yag baik adalah dapat melisiskan bakteri dalam saluran pencernaan sehingga penyerapan nutrisi lebih baik, dan didukung juga oleh Mihara et al., (1991).

Hari ke 3 fase pengendalian total koloni pada feses ayam memiliki jumlah (P0)8,63 Log CFU, (P1) 8,20 Log CFU, (P2) 8,36 (P3) 8,37 dan (P4) 8,37 dari hasil tersebut dapat dilihat bahwa rataan tertinggi terdapat pada perlakuan $(\mathrm{P} 0)$ pada perlakuan ini tidak memiliki imbuhan antibiotik sebesar 8,63 Log CFU yang diikuti secara berturut-turut oleh (P3) tepung L.rubellus 8,37 dan (P4) bubur L.rubellus yang memiliki rataan yang sama yakni sebesar 8,37 Log CFU dan terus diikuti oleh (P2) ekstrak L.rubellus sebesar 8,36 Log CFU dan (P1) 
imbuhan antibiotik buatan sebesar 8,20 Log CFU maka dilakukan analisis ragam sehingga di ketahui bahwa $\mathrm{F}$ hitung 856,67 lebih besar dari pada $\mathrm{F}$ tabel 0,05 sebesar 4,89 hal ini menjelaskan bahwasanya ada perbedaan antar perlakuan maka dilakuakan uji lanjut duncan untuk mengetahui perlakuan mana yang berbedanyata. Uji duncan dapat dilihat bahwa rataan tertinggi terdapat pada perlakuan (P0) tanpa imbuhan antibiotik sebesar 8,63 sebagai tertinggi dan diikuti dengan (P3) tepung L.rubellus dan (P4) yang memiliki notasi sama atau tidak berbeda nyata antara kedua perlakuan ini sebesar 8,37 dan 8,37 tetapi perlakuan ini tidak bisa mengimbangi (P2) ekstrak L.rubellus dengan rataan 8,36 hal ini membuktikan adanya perbedaan proses penyerapan P3, P4 dengan P2 pada perlakuan P2 dalam bentuk cair sedangkan P3 dan P4 lebih berserat P2 tidak dapat menyaingi (P1) penggunaan antibiotik komersil dalam ransum dengang nilai ratan sebesar 8,20 atau terendah dibandingkan dengan yang lainnya hal ini menjelaskan bahwa P0, P3, P4, dan P2 tidak dapat mengimbangai P1.

Hari ke 4 setelah masa inkubasi atau hari ke 13 pemeliharaan total koloni pada feses ayam memiliki jumlah (P0) 8,81 Log CFU, (P1) 7,96 Log CFU, (P2) 8,22 Log CFU, (P3) 8,23 Log CFU dan (P4) 8,23 Log CFU, pada hari ke 4 pemeliharaan rataan tertinggi pada perlakuan (P0) kontrol atau tidak menggunakan antibiotik yang diikuti berturut turut oleh P3 dan P4 dengan rataan yang sama diikuti dengan (P2) perlakuan ekstrak L.rubellus, dan yang terendah terdapat pada (P1) menggunakan antibiotik komersil dengan beragamnya nilai rataan pada setiap perlakuan maka dilakukan analisis ragam sehingga di ketahui bahwa $\mathrm{F}$ hitung 3530,78 lebih besar dari pada $\mathrm{F}$ tabel 0,05 hal ini dilanjutkan denga uji duncan untuk mengetahui tingkat keragaman antar perlakuan.

Uji duncan menjelaskan bahwa perlakuan tertinggi terdapat pada perlakuan P0 dengan rataan 8,81 yang diikuti berturut-turut oleh perlakuan $\mathrm{P} 2$, $\mathrm{P} 3$, dan $\mathrm{P} 4$ sebesar 8,22; 8,23; 8,23 dan yang terrendah terdapat pada P1 sebesar 7,96 hal ini diasumsikan karena pada hari ke 4 setelah pemberian perlakuan setiap perlakuan sudah tereaksi sempurna dalam saluran pencaenaan pada P3 dan P4 lebih lama tereaksi dan lebih lama berinteraksi denga Salmonella $s p$ Hal ini sesuai dengan Ardiansyah (2012) Ramuan herbal serbuk lebih lama berada dalam saluran usus dibanding ramuan herbal cair sehingga zat bioaktif mempunyai kesempatan kontak langsung untuk bekerja melisiskan bakteri yang menempel pada dinding usus sehingga dinding usus lebih mudah menyerap zat-zat nutrisi. Keadaan ini menyebabkan kondisi hewan menjadi lebih baik untuk mencegah penyakit Salmonellosis. Hal ini sesuai pendapat Banong et al., (2011) bahwa pembatasan aksesibilitas pakan selama \pm 3 jam, pakan dalam crop (tembolok) masih tersisa dengan kondisi telah mengalami pencampuran dengan air minum. Pembatasan aksesibilitas pakan yang dilakukan selama \pm 6 jam, kondisi crop, 
proventikulus dan gizzard ayam sudah kosong namun dengan usus halus yang masih penuh. Pada kondisi tersebut menandakan bahwa saluran pencernaan masih terisi dengan sisa pakan yang dikonsumsi sebelumnya.

\section{KESIMPULAN}

Salmonella sp dapat dikendalikan dengan olahan L.rubellus ditinjau dari tingkat pertumbuhan Salmonella sp yang beragam pada media agar yang berisi L.rubellus dan luas sensitifitas zona bening L.rubellus melalui pengolahan dalam bentuk ekstrak L.rubellus, tepung L.rubellus dan bubur L.rubellus. Pengolahan L.rubellus tidak dapat mengimbangi antibiotik komersil disebabkan tingkat konsentrasi larutan yang berbeda.

\section{DAFTAR PUSTAKA}

Ardiansyah. 2012. laporan penghitungan koloni bakteri. Laboratorium Mikrobiologi Sekolah Tinggi Penyuluhan Pertanian (STPP). Gowa

Baehaki, A., Rinto., Budiman, A. 2011. Isolasi dan Karakterisasi Protease dari Bakteri Tanah Rawa Indralaya, Sumatera Selatan. J.Teknol dan Industri Pangan, 22 (1): 37-42.

Banong, S. dan Hakim, M.R. (2011). Pengaruh Umur dan Lama Pemuasan Terhadap Performa dan Karakteristik Karkas Ayam Pedaging. JITP. 1(2): 98 - 106.

Brooks, Geo, F., Janet, S. B., Stephen, A. M., 2005. Mikrobiologi Kedokteran. Salemba Medika. Jakarta.

Capuccino, J. G., dan Sherman, N., 1978. Microbiology A Laboratory Manual. Rockland Community Collage. Suffern. New York.

Cho, J.H., C.B. Park, Y.G. Yoon dan S.C. Kim. (1998). Lumbricin I, a Novel Proline-Rich Antimicrobial Peptide from the Earthworm: Purification, cDNA Cloning and Molecular Characterization. Biochim. Biophys. Acta. 1408 (1): 67-76.

Dharmojono. 2001. Penyakit Tifus (Salmonellosis). Dalam Penyakit menular dari binatang ke manusia . Edisi Pertama . Milenia Populer. him. 111-121.

Gast, R.K. 1997. Paratyphoid infections . In Disease of Poultry. Tenth Edition. Calnek, B.W., H.J. Barnes, C.W.Beard, L.R.Mcdougald And Y.M. Saif. (Eds. Pp.97-112). Iowa State university Press, Ames, Iowa, USA.

Jay, J.M., 2000. Modern Food Microbiology, 6th.Ed. Aspen Publisher, Inc., Maryland. 
Lay, B.W (1994). Analisis Mikroba di Laboratorium. PT Raja Grafindo Persada. hlm. 68. Jakarta

Liu, Y-Q., Z-J. Sun, C. Wang, S-J. Li, and Y-Z. Liu. (2004). Purifi cation of a Novel Antibacterial Short Peptide in Earthworm Eisenia foetida. Acta Biochimica et Biophysica Sinica, 36 (4): 297-302

Mary E.B, 1992. Ilmu Gizi dan Diet, Yogyakarta. E. Medica.

Masduki. (1996). Efek Antibakteri Ekstrak Biji Pinang (Areca catechu) terhadap S. aureus dan E. coli. Jakarta: Penerbit Cermin Dunia Kedokteran. Hal. 23-24.

Mcmullin, P. 2004. A Pocket Guide to Poultry Health and Disease. 5M Enterprises Limited. Sheffield. Musnelina lili. 2004. Analisis Efektivitas Biaya Pengobatan Demam Tifoid Anak Menggunakan Kloramfenikol dan Seftriakson di Rumah Sakit Fatmawati Jakarta Tahun 2001-2002. http://repository.ui.ac.id (diakses tanggal 10 November 2009).

Mihara, H., H. Sumi, T. Yoneta, H.Mizumoto, R. Ikeda, M. Seiki dan M. Maruyama. 1991. A novel fibrinolityc enzyme extracted from the earthworm, Lumbricus rubellus. Japan J. Physiol. 41: 461-472.

Palungkun, R. 2008. Sukses Beternak L.rubellus Lumbricus rubellus. Penebar Swadaya. Jakarta. hal. 5-15.

Porter, R.E. 1998. Bacterial enteritides of poultry. Poult. Sci. 77: 1159-1165.

Seeley, H.W., P.J. Van Demark And J.J. Lee. 2001. Microbes In Action: A Laboratory Manual Of Microbiology 4th Edition. W.H. Freeman And Company, New York.

Shivaprasad, H.L. 2003. Pullorum Disease and Fowl Typhoid. in: Disease of Poultry. SAIF, Y.M. (Ed). 11th Edition. Iowa State Press, Ames, Iowa.

Syamsiah, S.I. dan Tajuddin. (2005). Khasiat dan Manfaat Bawang Putih Raja Antibiotik Alami. Cetakan IV. Agromedia Pustaka, Jakarta.

Tafsin, M. 2007. Kajian Polisakarida Mannan dari Bungkil Inti Sawit Sebagai Pengendali Salmonella Thypimurium dan Immunostimulan Pada Ayam. IPB Press. Bogor 